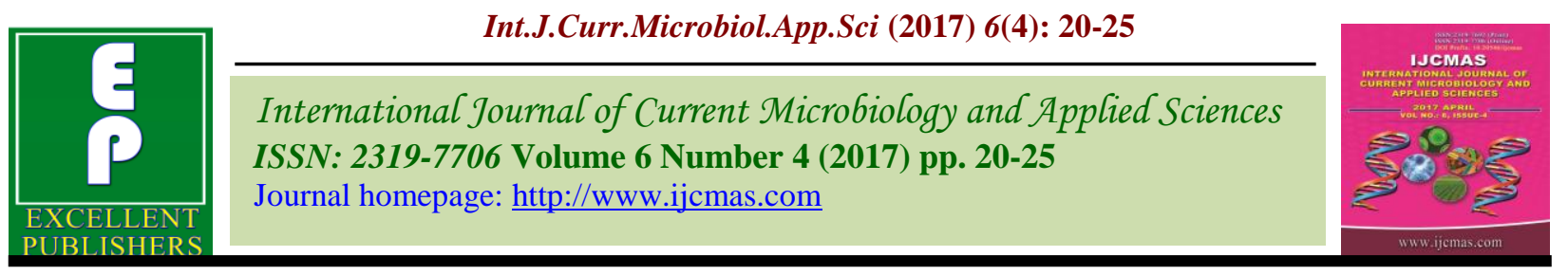

Original Research Article

https://doi.org/10.20546/ijcmas.2017.604.003

\title{
Genetic Character Variability Studies in Desi Chickpea (Cicer arietinum L.) Genotypes
}

\author{
Alka Dev*, Preeti Verma and Bheru Lal Kumhar \\ ${ }^{1}$ Department of Genetics and Plant Breeding, Institute of Agriculture Science, \\ Bundelkhand University, Jhansi - 284128 (U.P.), India \\ ${ }^{2}$ Agriculture University, Kota 324001, Rajasthan, India \\ *Corresponding author
}

\begin{tabular}{|c|c|}
\hline & A B S T R A C T \\
\hline & \multirow{5}{*}{$\begin{array}{l}\text { Keeping the importance of the crop and the aspects to be studied, the present investigation } \\
\text { entitled "Genetic Character Variability Studies in Desi Chickpea (Cicer Arietinum L.) } \\
\text { Genotypes)"was conducted in rabi2014-15 at the Research Farm of Agricultural Research } \\
\text { Station, Ummedganj, Kota, Agricultural University, Kota to assess the variance revealed } \\
\text { sufficient amount of variability present in the genotypes studied. Harvest index recorded } \\
\text { maximum phenotypic range of variation followed by } 100 \text { seed weight, number of pods per } \\
\text { plant, plant height and number of nodules per plant. The high to moderate genotypic } \\
\text { coefficient of variation and phenotypic coefficient of variation was observed for harvest } \\
\text { index, plant height, } 100 \text { seed weight and number of seeds per pods, seed yield per plant, } \\
\text { secondary branches per plant and primary branches per plant. The genotypic and } \\
\text { phenotypic path coefficient analysis revealed that biological yield per plant and harvest } \\
\text { index exhibited high and positive direct effects on seed yield per plant. The results of path } \\
\text { coefficient analysis revealed that for improvement of seed yield in chickpea through } \\
\text { selection programme, more emphasis should be given to harvest index, days to } 50 \% \\
\text { flowering number of seeds per pod and number of pods per plant. }\end{array}$} \\
\hline Keywords & \\
\hline Article Info & \\
\hline $\begin{array}{l}\text { 02 March } 2017 \\
\text { Available Online: } \\
10 \text { April } 2017\end{array}$ & \\
\hline & \\
\hline
\end{tabular}

\section{Introduction}

Chickpea (Cicer arietinum L.) is an annual legume crop. The genus Cicer belongs to the sub-family Papilionaceae of the family Leguminoceae, (Bentham and Hooker, 1970) now known as Fabaceae. Chickpea popularly known as gram, bengal gram, homes, chhola, garbenzo bean is one of the first grain legumes to be domesticated by humans in old world (Van der Maesen, 1972). The genus consists of 39 known species distributed mainly in central and western Asia, of which two species viz., Cicer arietinum $(2 \mathrm{n}=16)$ and C. soongaricum $(2 \mathrm{n}=16)$ are found to be cultivated in India. The origin of the crop is considered to be in Western Asia (Bouhadida et al., 2015), from where it spread in India and other parts of the world. India is a leading chickpea growing country accounting for about 65 per cent of the world production. Other countries include Iran, Iraq, Greece, Turkey, Afghanistan, Pakistan, Morocco, Mexico, Burma and Tanzania.

In India, chickpea is an important legume crops and plays an important role to improve soil fertility due to nitrogen fixation by 
Rhizobium bacteria found in its root nodules. It is capable of thriving in harsh and fragile environments. It has comparative advantage in contributing to crop diversification, rotation and mixed cropping. It is also called low agriculture input due to its nitrogen fixation property and an important source of vegetable protein. It is cultivated in semi arid tropics and West Asia North Africa (WANA) region on 11.6 million hectares area worldwide with 8.7 million tons of production (FAOSTAT, 2009).

Nutrition point of view, chickpea seeds contain $17.7 \%$ protein, $0.49 \%$ lysine, $0.11 \%$ methionine (Katiyar, 1982). In addition to this, it also carries $56.6 \%$ carbohydrates, ash, calcium, phosphorus, iron, and vitamin $\mathrm{B}$ in considerable amount (Thakur, 1980). In India, the area under chickpea was 8.74 million hectare with a production of 7.35 million tonnes with productivity of $841 \mathrm{~kg} / \mathrm{ha}$ during Rabi 2009-10 (Singh, 2010).

Four states viz., Madhya Pradesh, Uttar Pradesh, Maharashtra and Rajasthan together contribute about $87 \%$ of production from 65 $\%$ area. Besides these four states, Gujarat, Andhra Pradesh, Karnataka and Bihar are also the major chickpea growing states in the country. In Gujarat, area under chickpea was 2.50 lakh hectares with total production of 2.28 lakh tonnes and productivity of 913 $\mathrm{kg} / \mathrm{ha}$ during Rabi 2009-10 (Anonymous, 2010).

Chickpea is used as dal in split form and whole fried or boiled seeds are also eaten. Husk and bits of dal are used as nutritious feed for animals. Green immature chickpea is also used as vegetable and its flour is a major ingredient in snacks and sweets in India and Pakistan. Chickpea plant as such can also be used as green fodder, while straw is an excellent dry fodder for animals.
The basic rationale in any crop improvement programme is the increase in yield potential of the crop. Seed yield is a complex and polygenic trait, and in order to study it properly, different factors affecting the seed yield must be considered and evaluated with regard to their contribution to seed yield. For a particular crop, information on the nature and magnitude of variability present in the population due to genetic and non-genetic causes is an important pre-requisite for commencing any systematic breeding programme.

Availability of sufficient genetic variability is very important in a crop improvement programme. For successful breeding programme, amount of genetic variability present in the experimental material is a basic requirement. Therefore, it is essential for a plant breeder to measure the variability with the help of parameters like phenotypic coefficient of variation, genotypic coefficient of variation, heritability and genetic advance. Hence, these parameters give the information regarding the availability of genetic variability for different characters in available germplasm. Therefore, study of genetic variability of seed yield and its component characters among different varieties provides a strong basis for selection of desirable genotypes for augmentation of yield and other agronomic characters.

Different components of seed yield very often exhibit varying degree of associations with seed yield as well as among themselves. In order to accumulate optimum combination of seed yield contributing characters in a single genotype, it is essential to know the relationships among themselves.

Further, the seed yield is influenced by its various components directly and/or indirectly via other traits that create a complex situation before a breeder for making desirable 
selection. Therefore, path coefficient analysis could provide a more realistic picture of the interrelationship, as it partitions the correlation coefficient in direct and indirect effects of the variables.

Thus, character association and path analysis provide the information of yield contributing characters and breeder can practice selection using this information for the isolation of superior accession from gene bank.

\section{Materials and Methods}

Sixty genotypes of chickpea were sown during rabi 2014-15 in a randomized block design with three replications.

Each line was sown in a plot of $4.8 \mathrm{~m}^{2}$ area with a spacing of $30 \mathrm{~cm}$ row to row and 10 $\mathrm{cm}$ plant to plant. The genotypes were randomly allotted to the plots in each replication. All the recommended agronomical practices along with necessary plant protection measures were followed timely for the successful raising of crop.

\section{Results and Discussion}

The estimates of heritability in broad sense $\mathrm{H}^{2}{ }_{\mathrm{b}}$ for all the characters under study are presented in table 1. Very high estimates of heritability were recorded for pod length (98.98\%), number of nodules per plant (98.98\%), 100 seed weight (97.69\%), days to $50 \%$ flowering $(93.45 \%)$, days to maturity $(92.12 \%)$ (Table 2).

High to moderate values were recorded for, seed yield per plant (78.05\%), plant height $(75.39 \%)$, harvest index $(73.90 \%)$. Whereas, moderately low value of heritability were recorded for number of primary branches per plant (56.13\%), number of secondary branches per plant $(48.71 \%)$ and number of seed per pod $(33.27 \%)$.

\section{Genotypic and phenotypic coefficient of} variation

The estimate of genotypic and phenotypic coefficient of variability indicated that the values of phenotypic coefficient of variation were higher than genotypic coefficient of variation, in most of the cases, indicating more influence of environmental factors. The relative magnitude of difference between phenotypic coefficient of variation and genotypic coefficient of variation was low for number of pods per plant, number of seeds per pod, 100 seed weight, number of nodules per plant and days to $50 \%$ flowering indicating that these characters were less influenced by the environments. Similar results were also reported by Arora (1991), Wahid and Ahmed (1999), Nimbalkar (2000), Singh (2006) and Borate et al., (2010). These findings suggested that selection can be effective on the basis of phenotype along with equal probability of genotypic values.

\section{Correlation coefficients}

In the present investigation, most of the character pairs had higher values of genotypic correlations their corresponding phenotypic correlations. Such high amount of genotypic correlations could result due to masking or modifying effect of environmental on the association of characters. This indicates that though there was high degree of association between two variables at genotypic level, its phenotypic expression was deflated by the influence of environment. It was also indicated that there was inherent relationship between the characters studied which is in agreement with the findings of Raval (2001); and Vaghela et al., (2009). On the contrary, the phenotypic correlation coefficients found to be higher than their genotypic correlation coefficients may be due to the non- genetic causes probably environment inflated the value of phenotypic correlation. 
Table.1 List of sixty desi chickpea genotypes selected for the present investigation on genetic variability and association studies

\begin{tabular}{|c|c|c|c|}
\hline S.No. & Genotypes & S.No. & Genotypes \\
\hline 1 & RKG 12- 162 & 31 & RKG $13-541$ \\
\hline 2 & RKG 12- 130 & 32 & RKG $26-34$ \\
\hline 3 & RKG $11-157$ & 33 & RKG $13-516$ \\
\hline 4 & RKG $13-460$ & 34 & RKG $13-510$ \\
\hline 5 & RKG $13-454$ & 35 & RKG $13-450$ \\
\hline 6 & RKG $12-309$ & 36 & RKG $13-297$ \\
\hline 7 & RKG $12-298$ & 37 & RKG $11-05$ \\
\hline 8 & RKG $12-286$ & 38 & RKG $27-99$ \\
\hline 9 & RKG $12-172$ & 39 & RKG $13-105$ \\
\hline 10 & RKG $12-296$ & 40 & RKG $13-223$ \\
\hline 11 & RKG $13-105$ & 41 & RKG $13-403$ \\
\hline 12 & RKG $12-307$ & 42 & RKG $13-112$ \\
\hline 13 & RKG $12-158$ & 43 & RKG $13-113$ \\
\hline 14 & RKG $13-249$ & 44 & RKG $13-283$ \\
\hline 15 & RKG $13-521$ & 45 & RKG $13-91$ \\
\hline 16 & RKG $13-401$ & 46 & RKG $13-75$ \\
\hline 17 & RKG $13-501$ & 47 & RKG $13-205$ \\
\hline 18 & RKG $13-515$ & 48 & RKG $13-82$ \\
\hline 19 & RKG $13-504$ & 49 & RKG $13-61$ \\
\hline 20 & RKG $13-193$ & 50 & RKG $13-111$ \\
\hline 21 & RKG $13-150$ & 51 & RKG $13-22$ \\
\hline 22 & RKG $13-224$ & 52 & RKG $13-211$ \\
\hline 23 & RKG $13-545$ & 53 & RKG $13-83$ \\
\hline 24 & RKG $13-511$ & 54 & RKG $13-84$ \\
\hline 25 & RKG $13-02$ & 55 & RKG $13-54$ \\
\hline 26 & RKG $13-229$ & 56 & PC - 1 (Check) \\
\hline 27 & RKG $13-110$ & 57 & GNG - 469 (Check) \\
\hline 28 & RKG $13-186$ & 58 & JG - 14 (Check) \\
\hline 29 & RKG $13-166$ & 59 & GNG - 1581 (Check) \\
\hline 30 & RKG $13-208$ & 60 & JG- 2000 - 87 (Check) \\
\hline
\end{tabular}


Table.2 Genetic variability, PCV, GCV, heritability, genetic advance and genetic advance (as \% of mean) observed for desi chickpea genotypes

\begin{tabular}{|c|c|c|c|c|c|c|c|c|c|c|c|c|}
\hline $\begin{array}{c}\text { Parameters/ } \\
\text { Trait }\end{array}$ & $\begin{array}{c}\text { Days to } \\
\mathbf{5 0 \%} \\
\text { Flowering }\end{array}$ & $\begin{array}{c}\text { Days to } \\
\text { Maturity }\end{array}$ & $\begin{array}{c}\text { No of } \\
\text { Primary } \\
\text { Branches } \\
\text { per Plant }\end{array}$ & $\begin{array}{c}\text { No of } \\
\text { Secondary } \\
\text { Branches } \\
\text { per Plant }\end{array}$ & $\begin{array}{c}\text { Plant } \\
\text { Height } \\
\text { (cm) }\end{array}$ & $\begin{array}{c}\text { No of } \\
\text { Pods } \\
\text { per } \\
\text { Plant }\end{array}$ & $\begin{array}{c}\text { Pod } \\
\text { Length } \\
\text { (cm) }\end{array}$ & $\begin{array}{c}\text { Seeds } \\
\text { per } \\
\text { Pod }\end{array}$ & $\begin{array}{c}\text { No of } \\
\text { Nodules } \\
\text { per } \\
\text { Plant }\end{array}$ & $\begin{array}{c}100 \\
\text { Seed } \\
\text { Weight } \\
\text { (g) }\end{array}$ & $\begin{array}{l}\text { Harvest } \\
\text { Index }\end{array}$ & $\begin{array}{c}\text { Seed } \\
\text { Yield per } \\
\text { Plant } \\
\text { (g) }\end{array}$ \\
\hline Mean & 73.07 & 116.41 & 2.54 & 7.71 & 62.65 & 40.42 & 1.87 & 1.51 & 9.17 & 16.42 & 34.48 & 9.23 \\
\hline Range & $\begin{array}{c}65.3 \\
\text { to } \\
79.7\end{array}$ & $\begin{array}{c}111.7 \\
\text { to } \\
122.3\end{array}$ & $\begin{array}{l}1.9 \\
\text { to } \\
3.1\end{array}$ & $\begin{array}{c}5.3 \\
\text { to } \\
10.3\end{array}$ & $\begin{array}{c}29.1 \\
\text { to } 64.3\end{array}$ & $\begin{array}{c}24.7 \\
\text { to } \\
64.1\end{array}$ & $\begin{array}{l}1.3 \\
\text { to } \\
2.6\end{array}$ & $\begin{array}{l}1.3 \\
\text { to } \\
1.9\end{array}$ & $\begin{array}{c}5.1 \\
\text { to } \\
20.1\end{array}$ & $\begin{array}{c}9.4 \\
\text { to } \\
27.9\end{array}$ & $\begin{array}{c}17.3 \\
\text { to } \\
54.6\end{array}$ & $\begin{array}{c}4.4 \\
\text { to } 14.4\end{array}$ \\
\hline $\mathbf{P C V}$ & 4.62 & 2.33 & 2.13 & 5.10 & 7.63 & 15.35 & 3.14 & 1.09 & 10.99 & 10.45 & 17.15 & 7.63 \\
\hline GCV & 4.46 & 2.23 & 1.60 & 3.56 & 6.63 & 10.68 & 3.13 & 0.63 & 10.94 & 10.33 & 14.75 & 6.74 \\
\hline $\mathbf{H}_{b}^{2}$ & 93.45 & 92.12 & 56.13 & 48.71 & 75.39 & 48.39 & 99.63 & 33.27 & 98.98 & 97.69 & 73.90 & 78.05 \\
\hline GA & 6.48 & 3.10 & 0.23 & 0.83 & 5.30 & 5.70 & 0.52 & 0.05 & 3.98 & 4.99 & 8.98 & 2.18 \\
\hline GA \% Mean & 8.87 & 0.89 & 3.08 & 3.60 & 3.03 & 4.70 & 9.20 & 1.19 & 14.45 & 10.13 & 8.68 & 7.89 \\
\hline
\end{tabular}




\section{Path coefficient analysis}

The path coefficient analysis revealed that harvest index, days to $50 \%$ flowering number of seeds per pod and number of pods per plant exhibited high and positive direct effects on seed yield per plant. All these characters turned out to be the major component of seed yield. Positive moderate direct effect was observed for number of primary branches per plant whereas, negative was observed for days to maturity. High and positive direct effect of harvest index was also reported by Singh (2007), Thakur and Sirohi (2009), and Vaghela et al., (2009). The residual effect was of low magnitude suggesting that the majority of the yield attributes have been included in the path analysis.

\section{References}

Anonymous. 2010. District wise area, production and yield per hectare of important food and non-food crops in Gujarat state for the year 2009-10. Directorate of Agriculture, Gujarat State, Gandhinagar.

Arora, P.P. 1991. Genetic variability and its relevance in chickpea improvement. ICN., 25: 9-10.

Borate, V.V., Dalvi, V.V. and Jadhav, B.B. 2010. Estimates of genetic variability and heritability in chickpea. J. Maharashtra Agric. Univ., 35(1): 47-49.

Bouhadida Marien, Benjannet Rym, Jendoubi Warda, Kharrat Mohamed. 2015. Analysis of genetic diversity of Chickpea (Cicer arietinum L.) cultivars using STMS (Sequence Tagged Microsatellite Site) markers. IOSR J. Appl. Chem., (IOSR JAC) 8(2): 70-74.

FAOSTAT. 2009. Food and agricultural commodities production, Rome, Italy.

Katiyar, R.P. 1982. Accelerating pulse production in Himachal hills. Seeds and Farms, 8: 3742.

Nimbalkar, R.D. 2000. Genetic variability and heritability studies and scope for improvement in chickpea. J. Maharashtra Agric. Univ., 25: 109-110.

Raval, L.J. 2001. Studies on selection indices and genetic divergence in chickpea. M.Sc. Agri.) Thesis submitted to G.A.U., Sardarkrushinagar, Gujarat.

Singh, N.P. 2010. Project Coordinators Report. AICRP on chickpea, IIPR, Kanpur - 208 024.

Singh, S.P. 2006. Genetic variability and response to selection in chickpea (Cicer arietinum $\mathrm{L}$. Int. J. Plant Sci., 1: 232-233.

Singh, S.P. 2007. Correlation and path coefficient analysis in chickpea (Cicer arietinum L. Int. J. Plant Sci., 2(1): 1-4.

Thakur, S.K. and Sirohi, A. 2009.Correlation and path coefficient analysis in chickpea (Cicer arietinum L. Legume Res., 32(1): 1-6.

Thakur, C. 1980. Scientific crop production. Metropolotan Book Co. Pvt. Ltd.1 Netagi Subhash Marg, New Delhi, 10: 289-293.

Vaghela, M.D., Poshiya, V.K., Savaliya, J.J., Kavani, R.H. and Davada, B.K. 2009. Genetic variability studies in Kabuli chickpea (Cicer arietinum L. Legume Res., 32(3): 191-194.

Van der Maesen, L.J.G. 1972. Cicer L., A monograph of the genes with special reference to the chickpea, its ecology and cultivation Wageningen, the Netherlands.

Wahid, M.A. and Ahmed, R. 1998. Genetic variability correlation studies and their implication in selection of high yielding genotypes in chickpea (Cicer arietinum $\mathrm{L}$. Sarhad J. Agric., 15: 25-28.

\section{How to cite this article:}

Alka Dev, Preeti Verma and Bheru Lal Kumhar. 2017. Genetic Character Variability Studies in Desi Chickpea (Cicer arietinum L.) Genotypes. Int.J.Curr.Microbiol.App.Sci. 6(4): 20-25.

doi: https://doi.org/10.20546/ijcmas.2017.604.003 